\title{
Molecular signaling cascade of miRNAs in causing Diabetes Nephropathy
}

\author{
Dyave Gowda Padmashree \& Narayanaswamy Ramachandra Swamy*
}

Department of Biochemistry, Central College Campus, Bangalore University, Bangalore 560 001; Narayanaswamy Ramachandra Swamy - Email: drnrswamy@yahoo.com; Phone: 080-22961335; *Corresponding author

Received April 15, 2013; Accepted April 16, 2013; Published April 30, 2013

\begin{abstract}
:
Diabetic nephropathy $(\mathrm{DN})$ is one of the major microvascular diseases and most common in diabetic patient, finally results in kidney failure. The main features of $\mathrm{DN}$ are basement membrane thickening, microalbuminuria, proteinuria, glomerular, mesangial hypertrophy and ECM protein accumulation. Recent discoveries have been shown that numerous pathways are activated during the development of DN in Diabetes mellitus. The small non-coding miRNA plays an important role in regulating the pathway which is involved in DN. In our study we consolidate different pathways which regulated by miRNAs in molecular signaling which results in causing DN. We embedded entire pathway in the form of regulatory network and we could able to understand that some of the miRNAs like miR-29 family, miR-377 and miR-25 would be able to control DN.
\end{abstract}

Background:

Diabetic nephropathy (DN) is one of the major microvascular diabetic complication in diabetic patients have been seen in worldwide with the characteristic of hyperfilteration, basement membrane thickening, microalbuminuria, proteinuria, glomerular and mesangial hypertrophy and finally results in kidney failure [1-4]. TGF- $\beta$ expression is increased under diabetic condition in renal cell has been relatively increased in tubulointerstitial fibrosis, enlarged kidney glomeruli, fibronectin, EMT, proteinuria and excess collagen deposition [1, 3, 5-9].

Although a different key regulatory signaling pathway increases the DN includes inflammatory response and oxidative stress like NADPH oxidase leads to formation of superoxide in different cell/tissue $[8,10]$. MiRNAs (microRNAs) are small regulatory endogenous noncoding RNA with a length of 22-25 nucleotides present in all mammals, plants and virus. miRNA silence the target genes by binding to 3'UTR during transition and repress the target mRNA or degradation of mRNA by cleaving. miRNA play an important role in physiological and pathological in the development. Recent discoveries are to identify the miRNA and the target mRNA in different regulatory cascade of cancer cell. Recent review explains overall

ISSN 0973-2063 (online) 0973-8894 (print)

Bioinformation 9(8): 401-408 (2013) molecular target sites like RAAS, TGF- $\beta$, NADPH oxidase, p27 (Kip1) and adenosine are involved in the progression of DN [11]. Many studies explain the role of miRNA in DN. To prevent any diseases the molecular signaling cascade is important to understand. In this paper we consolidated different pathways which are regulated by miRNA in molecular signaling which result in causing $\mathrm{DN}$, embed the entire pathway in the form of regulatory network and found out some of the miRNAs control the regulation to prevent $\mathrm{DN}$.

\section{Methodology: \\ Data Mining}

The data were collected from maximum published papers on diabetes nephropathy relating to miRNA and their regulation models which are tabulated in Table 1 (see supplementary material). Finally with inter-bridging the data of observations and form a new molecular signaling cascade of miRNA (Figure 1).

\section{Sequence Analysis}

Pre-mature and mature miRNA sequences which are involved in the diabetes nephropathy are obtained from microRNA.org (http://www.microrna.org) which was stored in FASTA format and analyzed for further studies. Stored sequences are imported to Geneious 5.6.4 software for aligning the sequences. The entire 
pre-mature miRNA sequences are aligned by using CLUSTALW tool in multiple alignments. Among them some of the sequences show similarities in the sequences which are discussed more in results.

\section{Results \& Discussion:}

\section{Data compilation}

The data's were collected from various journals with reference to miRNA and diabetic nephropathy, then we started pulling out the information with the headlines- name of the organism, name of miRNA, miRNA target mRNA, types of the cell/tissues, regulation of miRNA in a cell, effect of miRNA interaction, in experimental condition like presence of $\mathrm{HG}$ or TGF- $\beta$ which simulate the diabetic milieu and also the pathway involved. Entire data had been examined and consolidated as show in Table 1.

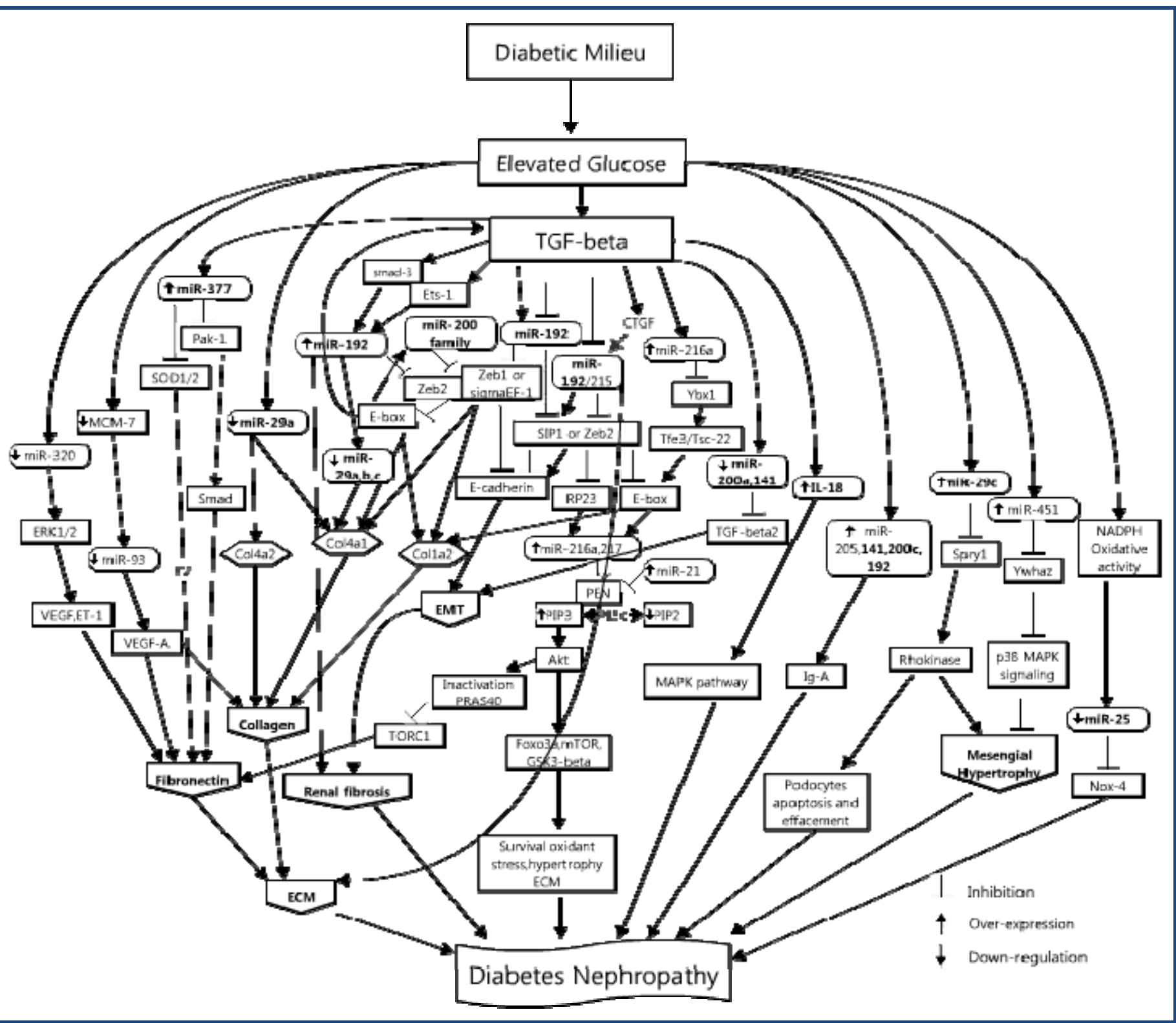

Figure 1: Outline of regulatory network complexity involved in diabetes nephropathy. The possible biomarker miRNA names are bold in the network.

Diabetes Nephropathy Network regulated by miRNAs

We collected data from various schools of thoughts and tried to consolidated information in the form of a network which states the regulation of different miRNAs in different types of cells in the kidney by causing DN.

Numerous studies have revealed the major causes of DN. Although our finding from previously existing studies, the earlier reports have explained the features in causing DN including ECM accumulation, fibronectin, collagen deposition, hypertrophy and EMT which is regulated by small non-coding RNA (miRNA). In our current studies, we explained different miRNAs involved in targeting the features of $\mathrm{DN}$ in progression of the disease. HG/TGF- $\beta$ is mainly involved in causing DN regulated by different pathways.

The regulatory network was drawn by consolidating all the molecular signaling. The idea behind this regulatory network is 
to understand different types of miRNAs regulation (Overexpression/ Down-regulation) which contributed to different types of cell in the kidney and also to identify a key regulatory miRNA which are involved in progression of DN (Figure 1). In mammalian model the major renal abnormalities includes tubulointerstitial fibrosis, low glomerular filtration rate [1] glomerulosclerosis [12] mesangial and $\lg$ A hypertrophy [13-15] podocytes effacement and apoptosis which leads to DN [13].

Numerous studies have been examined to understand the mechanism of miRNA expression in-vivo and in-vitro model by treating the cell with TGF- $\beta$ or HG to induced diabetes. Evidence shows that increased expression of TGF- $\beta$ is observed in renal cell under the diabetic condition $[16,17]$. In in-vitro studies different type of renal cells such as PTC, MC, glomeruli endothelial cell, HUVEC and renal cortical cell are used.

In mouse three E-box elements are present at the enhancer region of Col1a2 gene transcription start site [18]. Suppressor of E-box element by Zeb1 (also known TCF8/Sef1/nil-2a) and Zeb2 (SIP1/ZFXHIB) $[4,1]$ were regulated by miR-192, miR-215 and miR-200 family member $[5,1,18-20,8,4]$. Increased expression of miR-192 in mouse MC involves in enhancing col1a2 expression by down-regulating the SIP1 in response to TGF- $\beta 1$ [18]. In human and rat PTC miR-192 were downregulated by enhanced collagen and fibrosis in diabetic condition $[5,1]$. Another study shown that in rat PTC, MC and in human podocytes cells miR-192/215 were down-regulated by zeb2 and enhanced E-cadherin expression [9]. In addition miR-192 regulate miR-200 family, col1a1, col4a1 and TGF- $\beta 1$ through suppressor of E-box element by repressing Zeb1/2 in mouse MC by TGF- $\beta 1$ [4]. Over-expression of miR-192 is observed in MC of mouse [18, 4] and in PTC miR-192 were down-regulated $[9,5,1]$. It is interested to note that miR-192 regulation is different in two types of cells. This also suggested that even though the miRNA expression is different in cells, but the biological effect of miRNA in the kidney remains the same.

In mouse genome the miR-200 family is present in two clusters of less than $2000 \mathrm{bp}$ cluster 1 located on chromosome 4 contain three miRNA namely miR-200a, 200b and miR-429. Cluster 2 located in a 500bp region of chromosome 6 which includes miR200c and miR-141. The seed sequences of all five miRNAs in miR-200 family are similar [9]. In human genome miR-141 and miR-200c genes are located on chromosome 12p13.31. The spacer sequences are separated by $388 \mathrm{bp}$ other miRNA cluster are located on chromosome $1 \mathrm{p} 36$ [19]. Over-expression of miR200c in human cancer cell line A5A9 leads to reduced TCF-8 (zeb1) resulting in altered cell morphology and increased in expression of E-cadherin [20] similar studies in mouse carcinoma cell line NMUMG treated with TGF- $\beta$ induced EMT and enhanced E-cadherin by repressing Zeb1 and Zeb2 through ectopic expression of miR-200 family member [9]. In undifferentiated cancer cell over-expression of miR-141 and miR-200c leads to decreased TGF- $\beta$ and Zeb1 induces MET and expression of E-cadherin [19]. Recent reports have shown that down-regulation of miR-200a and miR-141 induced EMT and fibrogenesis in NRK52E cell in diabetic mice [7]. Fibrogenesis is associated with typical change in EMT and decreased expression of E-cadherin in tubular renal cell by TGF- $\beta$. TGF- $\beta$ also induced expression of CTGF which in turn increased miR192/215 level by inhibiting Zeb2 and consequently increased Ecadherin expression. In PTC both CTGF and TGF- $\beta$ results in increased ECM production [5]. Thus various studies show that miR-200 family member and miR-192/215 involved in regulation of E-cadherin and EMT by targeting Zeb1/2 in diabetic condition.

Under diabetic condition in mouse MC, TGF- $\beta$ induced upregulation of miR-192 repressing Zeb2. Repressed Zeb2 enhanced RP23. miR-216a and 217 are located within second introns of RP23 in mouse chromosome 11 and in human genome it is located on chromosome 2. Further miR-216a and 217 promote activation of Akt, increased Foxo3a, mTOR, GSK3$\beta$ caused survival oxidant stress and ECM expression hypertrophy, and these are the characteristics of $\mathrm{DN}$ [3]. Other studies in MC of diabetic mice shown that miR-21 downregulate PTEN and activation of P13K/Akt pathway which played a protective role in renal MC hypertrophy [14]. Recent studies showed that in T1D mice increased level of miR-21 reduced PTEN and enhanced phosphorylation of Akt resulting in the inactivation of PKAS40, there by increased TORC1 activity lead to increased fibronectin content in MC and PTC in response to HG [2]. In diabetic mouse over-expression of miR216a by targeting Ybx1 lead to increased expression of collagen in glomeruli and MC [21].

In presence of HG/TGF- $\beta$ in HK-2 cell induced downregulation of miR-29a, increased collagen IV deposition in PTC [22]. Similar studies showed that increased collagen expression of col-1, III and IV reducing miR-29a/b/c results in increased expression of ECM protein under TGF- $\beta$ treatment [23]. In mouse kidney glomeruli cell over-expression of miR-29c induced apoptosis and increased fibronectin through spry1/Rho-kinase pathway [13]. The studies suggest that miR29 family is mainly involved in collagen deposition in turn increased ECM protein in diabetes which is the main cause of DN.

Inflammatory stimuli and reactive oxygen species induced by TGF- $\beta$ in diabetic condition which progress for DN. TGF- $\beta$ leads to increase in IL- 8 expression in human PTC through the activation of MAPK pathway [8]. In presence of HG in MC, downregulation of miR-25 regulate redox signaling molecules [24]. Similar study in MC oxidative stress increased expression of miR-377 lead to enhanced fibronectin protein by reduced expression of superoxide dismutase and PAK1 in DN [10].

Vascular endothelial growth factor (VEGF) is one of the aspects mainly involved in microvascular complication of diabetes majorly in DN [11]. In diabetic condition miR-93 regulates VEGF expression. In mouse miR-93 is located within the intron 13 of MCM7 gene. Downregulation of miR-93 by targeting VEGF-A which leading to diabetic nephropathy in mouse podocytes [25]. In human umbilical vein endothelial cell (HUVEC) HG induced downregulation of miR-320 with consequently increased multiple molecules like ET-1, ERK1, VEGF and FN [26]. 
In the network (Figure 1) we have shown the different pathways regulated by miRNA which contributed to cause DN. Controlling the expression of miRNAs (Overexpression/Down-regulation) would prevent the progression of disease. Recent studies have been shown that LNA-anti-192 act as a potential therapeutic molecule preventing DN. LNA-anti192 injected to diabetic mice with both short and long term periods (2-17 weeks) significantly decrease the expression level of miR-192. It also attenuated the key features in causing the DN such as col1a2, col4a1, TGF- $\beta$, CTGF and FN which is regulated by E-box repressor Zeb1/2. Renal hypertrophy in diabetic mice can also be prevented by injecting with LNA-anti192. LNA-anti-192 inhibit Akt signaling pathway leading to decreased hypertrophy and oxidant stress and also decreased proteinuria and albuminuria in diabetic animal without increased in toxicity [27]. This shows that miR-192 act as central molecules by controlling the regulation of other miRNA. Other studies show that in DN mice miR-21 were down-regulated. Over-expression of $\mathrm{miR}-21$ acts as a protective role in glomerular hypertrophy in DN by downregulation of PTEN and activation of P13k/Akt pathway in kidney [14]. Data compilation from various schools of thoughts, we suggested that down-regulation of miR-377, miR-29c and IL-18 by LNAanti-miRNA or inhibitor which inhibit the oxidative stress, hypertrophy, podocytes apoptosis and effacement in turn prevent the DN. Likewise expression of miRNA like miR-29a and miR-25 through the insertion of miRNA by plasmid injection which inhibit oxidation and collagen production to prevent DN. A further study is required for clinical trial approaches. miRNAs act as key regulator molecules in diseases.

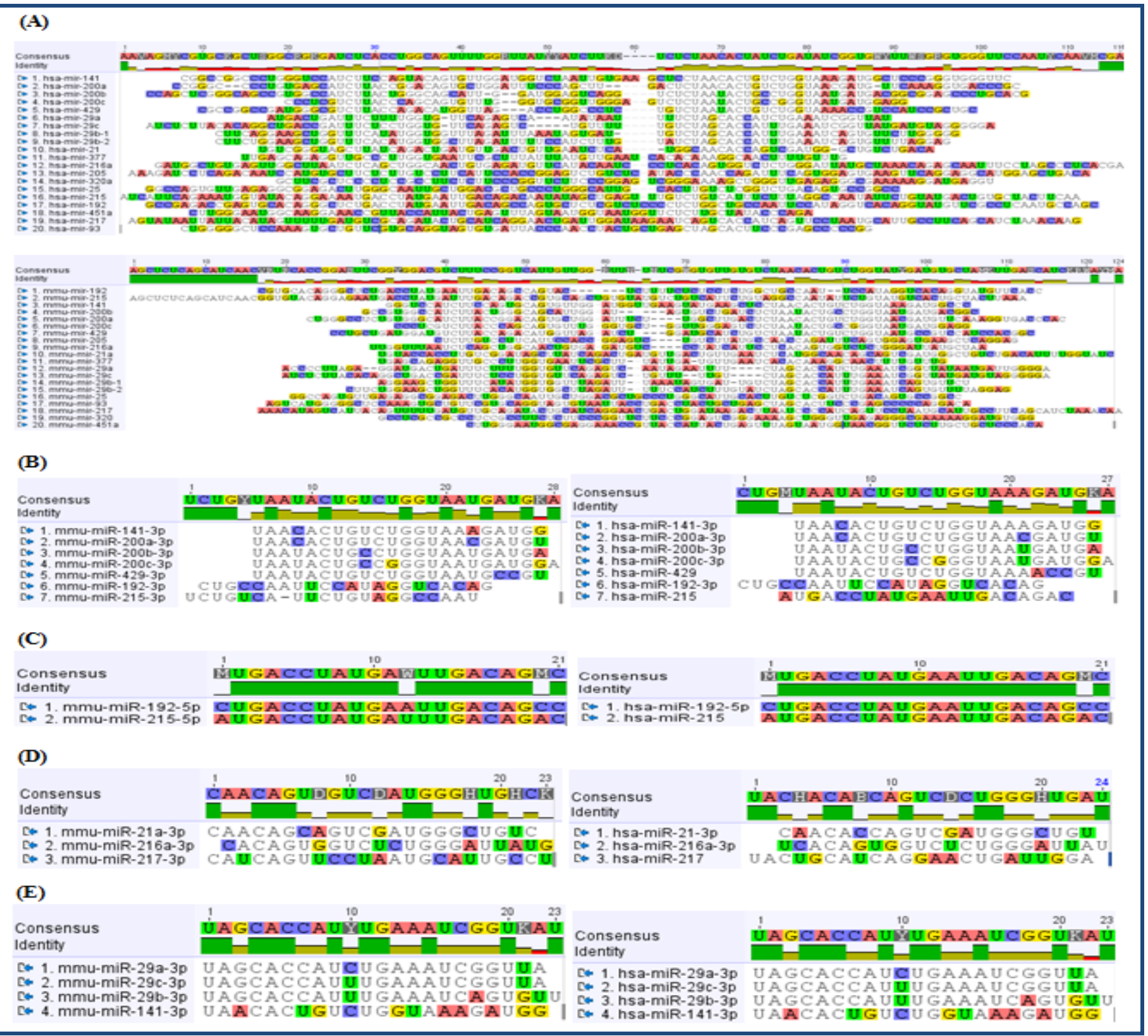

Figure 2: Pre-mature and mature miRNA sequence alignments in mouse and human by using Geneoius software. 


\section{Analysis of miRNA sequence}

Further, we analyzed the miRNAs sequences to determine the identical region of similarity that show commonality in evolutionary, structural or functional aspects, for this we used simple alignment tool (pairwise alignment and multiple alignment).

We analyzed the sequences of pre-mature miRNAs involved in the regulatory network Figure $\mathbf{2 A}$, from the regulatory network we observed only few of the miRNAs sequence are conserved and identical which are targeted to same mRNA. Zeb2 is target to different miRNAs like miR-200 family (miR-200a, 200b, 200c, 141 and 429), 215 and 192 all this sequence are approximately conserved Figure 2B. In miR-200 family member contains five miRNAs have similar sequences in mature miRNA. The seed sequence of miR-200b, miR-200c, and miR-429 is UCAUAA, differs only by one nucleotide to the seed sequence UCACAA of miR-200a and miR-141 [9]. miR-192 and 215 regulated by zeb2, there is $100 \%$ similarity in human, where as in case of mouse a single nucleotide change between miR-192 and miR215 Figure 2C. miR-21, 216a and 217 are target to PTEN the sequence are conserved and show similarly in functions Figure 2D. Further our analysis shows that miR-29 family and miR-141 have similarity in sequence they may have commonality in functions Figure 2E.

\section{Conclusion:}

Diabetes nephropathy is one of the major complex disease in diabetic patients and the complication lead to kidney failure. Prevention of the DN is a challenging task in today's world. Because due to it complication and unusual molecular mechanism includes inflammatory cytokines, oxidation, stress and also different miRNAs regulation contributes to DN. The identification of initial molecular mechanism acts as a significant factor and new therapeutic approaches to cure DN complication. In our study, we have showed few of the miRNAs in the regulatory network which could have played a role as a biomarker to prevent DN. A further clinical trial approach is necessary.

\section{Acknowledgement:}

We are grateful to online databases miRBase (http:/ /www.mirbase.org/), NCBI (http://www.ncbi.nlm.nih.gov) and online diagram drawing software lovely chart. This work was supported by University Grants Commission, New Delhi.

\section{References:}

[1] Krupa A et al. J Am Soc Nephrol. 2010 21: 438 [PMID: 20056746]

[2] Dey N et al. J Biol Chem. 2011 286: 25586 [PMID: 21613227]

[3] Kato M et al. Nat Cell Biol. 2009 11: 881 [PMID: 19543271]

[4] Kato M et al. Kidney Int. 2011 80: 358 [PMID: 21389977]

[5] Wang B et al. Diabetes. 2010 59: 1794 [PMID: 20393144]

[6] Zhang Z et al. FEBS Lett. 2012 586: 20 [PMID: 21827757]

[7] Wang B et al. Diabetes. 2011 60: 280 [PMID: 20952520]

[8] Miyauchi K et al. Diabetes Res Clin Pract. 2009 83: 190 [PMID: 19110334]

[9] Korpal M et al. J Biol Chem. 2008 283: 14910 [PMID: 18411277]

[10] Wang Q et al. FASEB J. 2008 22: 4126 [PMID: 18716028]

[11] Arora MK et al. Vascul Pharmacol. 2013 58: 259 [PMID: 23313806]

[12] Chung AC et al. J Am Soc Nephrol. 2010 21: 1317 [PMID: 20488955]

[13] Long J et al. J Biol Chem. 2011 286: 11837 [PMID: 21310958]

[14] Zhang Z et al. FEBS Lett. 2009 583: 2009 [PMID: 19450585]

[15] Wang G et al. Lab Invest. 2010 90: 98 [PMID: 19901913]

[16] Yamamoto T et al. Proc Natl Acad Sci USA. 1993 90: 1814 [PMID: 7680480]

[17] Ziyadeh FN, Am J Kidney Dis. 1993 22: 736 [PMID: 8238022]

[18] Kato M et al. Proc Natl Acad Sci U S A. 2007 104: 3432 [PMID: 17360662]

[19] Burk U et al. EMBO Rep. 2008 9: 582 [PMID: 18483486]

[20] Hurteau GJ et al. Cancer Res. 2007 67: 7972 [PMID: 17804704]

[21] Kato M et al. J Biol Chem. 2010 285: 34004 [PMID: 20713358]

[22] Du B et al. FEBS Lett. 2010 584: 811 [PMID: 20067797]

[23] Wang B et al. J Am Soc Nephrol. 2012 23: 252 [PMID: 22095944]

[24] Fu Y et al. Am J Nephrol. 2010 32: 581 [PMID: 21071935]

[25] Long J et al. J Biol Chem. 2010 285: 23457 [PMID: 20501654]

[26] Feng B et al. ISRN Endocrinol. 2012 2012: 549875 [PMID: 22900199]

[27] Putta S et al. J Am Soc Nephrol. 2012 23: 458 [PMID: 22223877]

Edited by P Kangueane

Citation: Padmashree \& Swamy, Bioinformation 9(8): 401-408 (2013)

License statement: This is an open-access article, which permits unrestricted use, distribution, and reproduction in any medium, for non-commercial purposes, provided the original author and source are credite 
BIOINFORMATION

\section{Supplementary material:}

Table 1: Table of distances pairwaise score generated in $\mathrm{VH}$

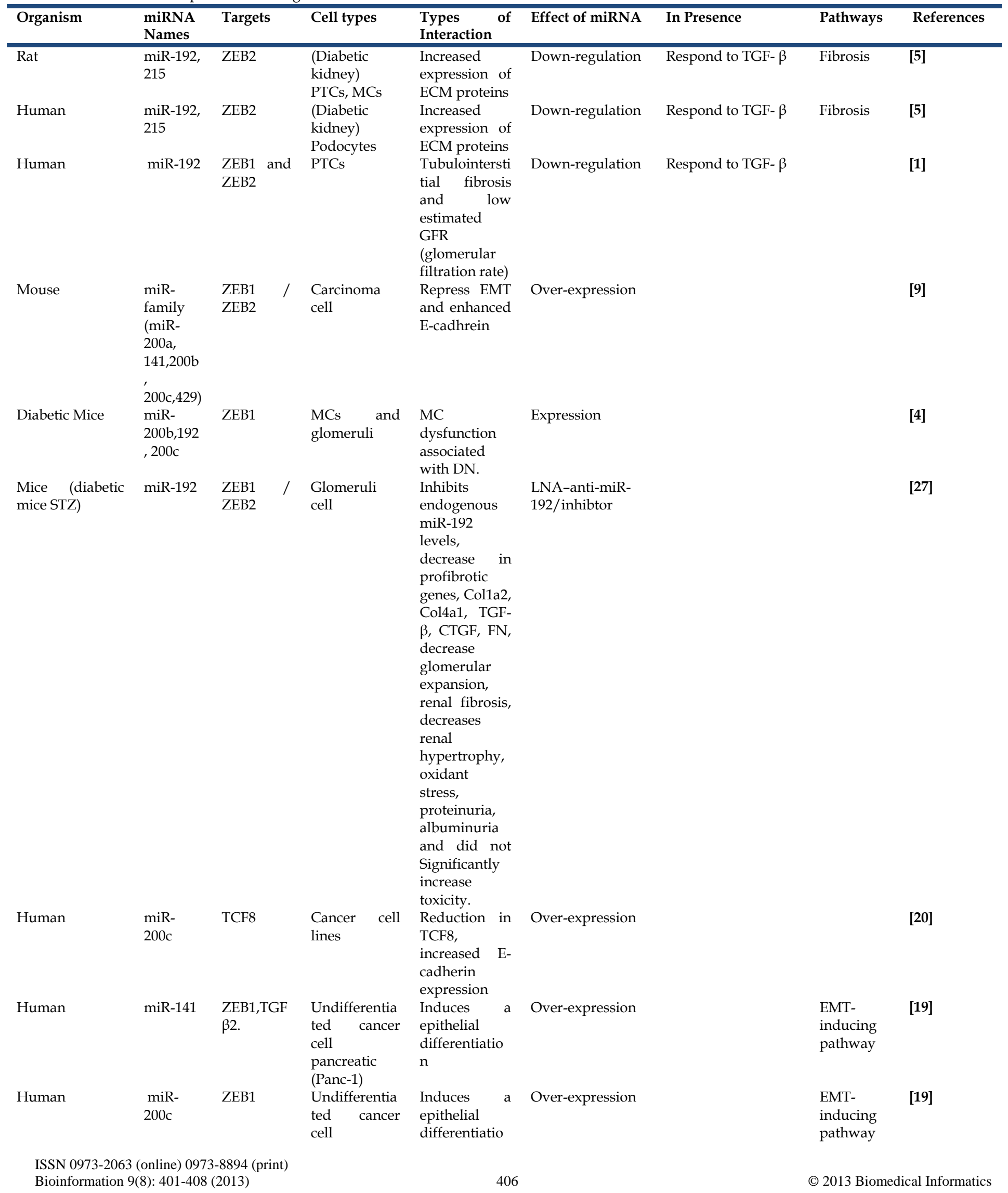




\begin{tabular}{|c|c|c|c|c|c|c|c|c|}
\hline & & & $\begin{array}{l}\text { pancreatic } \\
\text { (Panc-1) }\end{array}$ & $\mathrm{n}$ & & & & \\
\hline Diabetic Mice & $\begin{array}{l}\text { miR- } \\
\text { 141,miR- } \\
\text { 200a }\end{array}$ & TGF- $\beta 2$ & $\begin{array}{l}\text { Cortex of } \\
\text { kidneys }\end{array}$ & $\begin{array}{l}\text { Induced EMT } \\
\text { and } \\
\text { fibrogenesis }\end{array}$ & Down-regulation & Respond to TGF- $\beta 1$ & & [7] \\
\hline Diabetic Mouse & miR-21 & PTEN & $\begin{array}{l}\text { Renal MCs } \\
\text { and PTE cells }\end{array}$ & $\begin{array}{l}\text { Enhanced } \\
\text { phosphorylati } \\
\text { on of Akt, } \\
\text { and induced } \\
\text { increase in } \\
\text { fibronectin } \\
\text { expression }\end{array}$ & Expression & $\begin{array}{l}\text { HG stimulated } \\
\text { expression of miR- } \\
21\end{array}$ & $\begin{array}{l}\text { PI3- } \\
\text { kinase/Ak } \\
\mathrm{t}\end{array}$ & [2] \\
\hline Diabetic Mice & miR-21 & PTEN & $\begin{array}{l}\text { Renal cortical } \\
\text { tissue ( MCs ) }\end{array}$ & $\begin{array}{l}\text { Inhibited } \\
\text { mesangial } \\
\text { cells } \\
\text { proliferation }\end{array}$ & Over-expression & $\begin{array}{l}\text { Injection plasmids } \\
\text { containing miR-21 }\end{array}$ & $\begin{array}{l}\text { Activation } \\
\text { of } \\
\text { PI3K/Akt } \\
\text { pathway }\end{array}$ & [14] \\
\hline Diabetic Mice & $\begin{array}{l}\text { miR- } \\
216 a, 217\end{array}$ & PTEN & $\begin{array}{l}\text { Glomerular } \\
\text { MCs }\end{array}$ & $\begin{array}{l}\text { Activated Akt } \\
\text { and increased } \\
\text { mesangial } \\
\text { cells survival } \\
\text { and } \\
\text { hypertrophy }\end{array}$ & Expression & Respond to TGF- $\beta 1$ & & [3] \\
\hline Mouse & $\operatorname{miR}-29 c$ & SPRY1 & $\begin{array}{l}\text { Kidney } \\
\text { glomeruli } \\
\text { (podocytes } \\
\text { cell) }\end{array}$ & $\begin{array}{l}\text { Promotes Rho } \\
\text { kinase } \\
\text { activation, } \\
\text { leading to } \\
\text { enhanced cell } \\
\text { apoptosis and } \\
\text { increased } \\
\text { fibronectin } \\
\text { synthesis. }\end{array}$ & Over-expression & Respond to HG & $\begin{array}{l}\text { Spry1/Rh } \\
\text { o kinase } \\
\text { pathway }\end{array}$ & [13] \\
\hline Mouse & $\operatorname{miR}-29 \mathrm{c}$ & SPRY1 & $\begin{array}{l}\text { kidney } \\
\text { glomeruli } \\
\text { (microvascul } \\
\text { ar endothelial } \\
\text { cells) }\end{array}$ & $\begin{array}{l}\text { Promoted } \\
\text { activation of } \\
\text { Rho kinase } \\
\text { and } \\
\text { Mesangial } \\
\text { matrix } \\
\text { accumulation }\end{array}$ & Over-expression & Respond to HG & & [13] \\
\hline Mouse & $\operatorname{miR}-29 c$ & SPRY1 & $\begin{array}{l}\text { Kidney } \\
\text { glomeruli }\end{array}$ & $\begin{array}{l}\text { Prevented } \\
\text { high glucose- } \\
\text { induced cell } \\
\text { apoptosis. }\end{array}$ & Down-regulation & HG Anti-miR-29c & & [13] \\
\hline $\begin{array}{l}\text { Human and } \\
\text { Mouse }\end{array}$ & miR-377 & $\begin{array}{l}\text { SOD1, } \\
\text { SOD2, and } \\
\text { PAK1 }\end{array}$ & MCs & $\begin{array}{l}\text { increased } \\
\text { oxidative } \\
\text { stress and } \\
\text { fibronectin } \\
\text { protein } \\
\text { production }\end{array}$ & Over-expression & $\begin{array}{l}\text { Respond to HG } \\
\text { and TGF- } \beta\end{array}$ & & [10] \\
\hline Diabetic Mice & miR-451 & YWHAZ & MCs & $\begin{array}{l}\text { Inhibits the } \\
\text { glomerular } \\
\text { mesangial cell } \\
\text { proliferation }\end{array}$ & Over-expression & & $\begin{array}{l}\text { p38MAPK } \\
\text { pathway }\end{array}$ & [6] \\
\hline Rat & miR-192 & & $\begin{array}{l}\text { kidney } \\
\text { disease } \\
\text { (unilateral } \\
\text { ureteral } \\
\text { obstruction } \\
\text { (UUO)), TEC }\end{array}$ & $\begin{array}{l}\text { Renal fibrosis } \\
\text { (enhanced } \\
\text { TGF- } \beta 1- \\
\text { induced } \\
\text { tubular } \\
\text { collagen I } \\
\text { expression) }\end{array}$ & Over-expression & $\begin{array}{l}\text { Respond to TGF- } \beta 1 \\
\text { and TGF- } \beta 2\end{array}$ & $\begin{array}{l}\text { TGF- } \beta \\
\text { /Smad } \\
\text { signaling }\end{array}$ & [12] \\
\hline DN Human & miR-320 & & DN HUVECs & $\begin{array}{l}\text { Glucose } \\
\text { induced } \\
\text { upregulation } \\
\text { of endothelin } \\
1 \text { (ET-1), } \\
\text { multiple } \\
\text { vasoactive } \\
\text { factors and }\end{array}$ & Down-regulation & Respond to HG & & [26] \\
\hline
\end{tabular}




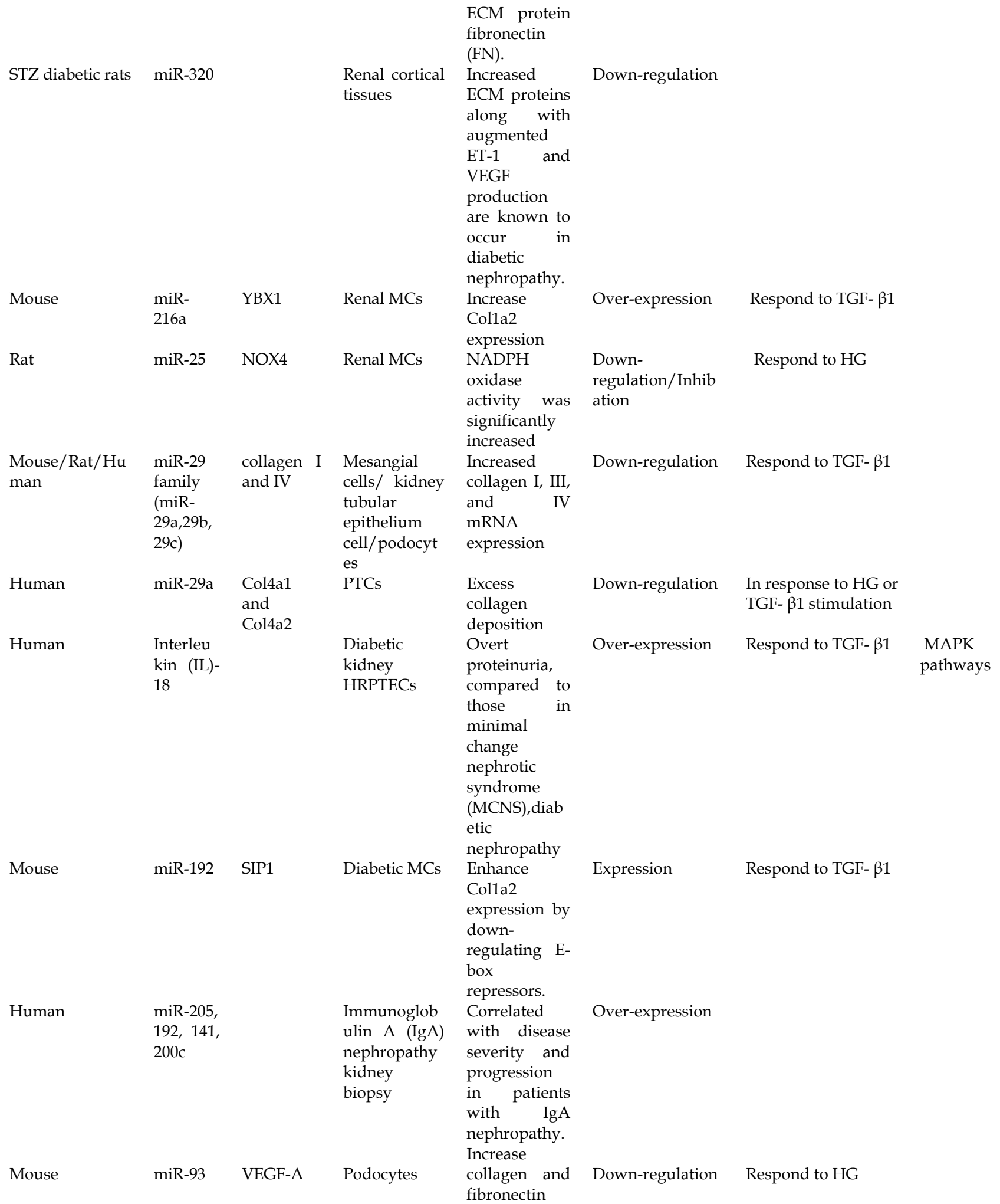

\section{Abbreviations:}

Diabetic Nephropathy (DN); High glucose (HG); TGF- $\beta 1 / 2$ (transforming growth factor, beta 1/2); Mesangial cells (MCs); Proximal tubular cells (PTCs); Proximal tubular epithelial (PTE) cells; Tubular epithelial cells (TEC); Human umbilical vein endothelial cells (HUVECs); Human renal proximal tubular epithelial cells (HRPTECs); Zinc finger E-box binding homeobox 1/2 (ZEB1/2); Phosphatase and tensin homolog (PTEN); Sprouty homolog 1 (Spry1); Tyrosine3-monooxygenase/tryptophan 5-monooxygenase activation protein, zeta (Ywhaz); Y box binding protein 1 (Ybx1); NADPH oxidase 4 (NOX4); P21-activated kinase (PAK1) ; Superoxide dismutase (SOD1/2); Smad-interacting protein 1 (SIP1); Transcription factor 8 (TCF8); Vascular endothelial growth factor-A (VEGF-A); Epithelial to mesenchymal transition (EMT); Fibronectin (FN); Locked nucleic acid (LNA); Extra cellular matrix (ECM). 